\title{
DETERMINANTS OF THE PERFORMANCE OF MICROFINANCE BANKS IN CANE ENHANCING AND ITS IMPACT ON SUGAR INDUSTRY OF SINDH
}

\author{
Murtazain Raza \\ PhD Scholar, Faculty of Social Sciences \& Humanities, \\ Hamdard University, Karachi, Pakistan \\ murtazainraza@gmail.com \\ Muhammad Akhtar Kang \\ Assistant Professor, Faculty of Social Sciences \& Humanities, \\ Hamdard University, Karachi, Pakistan \\ dr.akhtar@hamdard.edu.pk \\ Ahmad Saeed \\ Professor, Faculty of Social Sciences \& Humanities, \\ Hamdard University, Karachi, Pakistan \\ saeedahmadresearch@gmail.com
}

\begin{abstract}
Sugar cane is the second biggest cash crop of Pakistan, which contributes $3.4 \%$ to national income and 0.7 percent in gross domestic product as well sugar cane provides ecologically best stimulus for economic development. We cannot refute the importance of sugar cane cultivator's participation in this sector. This research study is organized to identify Determinants of the Performance Microfinance Banks in Cane Enhancing and its Impact on Sugar Industry of Sindh. Data was collected from 250 respondents were interviewed Sugar Cane Growers (SCG) and Agriculture Expert (AE) as wellstructured through purposive sampling technique within asymmetric survey methodology conducted. $S C G$ and AE remains $63 \%$ respondents were illiterate and their main occupation crop cultivation of sugar cane crop $76.7 \%$ respondents cultivating less than 12.5 acres and $20 \%$ respondents cultivating less than 25.0 acres in Sindh which is the largest population around $70 \%$ families stays in below the poverty line. This area demand attention. Sugar Cane is an integral part of agriculture and this sector is fulfilling the provincial demand of the country. State should support and privilege the efforts of the $S C G$ and AE for grow up and help them to crop cultivation for extent of the on-farm practices on high input cost and equal income equilibrium as far as cultivation high input costing so they can get guidance of Prudential Regulations and Agriculture Financing for the take care of them, on farm activities and pricing should have to subsidized. Micro finance institutions should play an integral part for sustainable economic agriculture development, going forward research emphasis to empower sugar cane population in which the segment should grow. The government and Microfinance banks should focus on promotion and paid participation in agricultural activities, monetary benefits as well as power of decision making with the recognition of their work.
\end{abstract}

Keywords: Production Cost, Agricultural Labor Markets, Support Price, Agriculture, Irrigation, Research and Development.

\section{INTRODUCTION}

Pakistan is agriculture state which contributes $19.3 \%$ in gross domestic product of the country although the share performance diminishing in these years (Economic Survey of Pakistan, 2019-20). In neighboring agro-based state like Bangladesh, the researcher found their Micro Financial Institutions Banks annually disbursed agriculture financing loans from 30 million members with over $\$ 2$ billion over the past two decades as their bio products highly reliant sugar cane only source of white sugar in Bangladesh, researcher have found that micro financing scheme have offered multiple agriculture financing schemes for male and female growers and agriculturist's benefits the poor by raising promotion but unluckily unequal income distribution caused by large and small medium male and female levels growers in farm communities borrowing issues (Khandker, \& Samad, 2014). Although in neighboring country India is a largest agriculture State, another researcher found that performance yield gap was attributable the growers typically resist to accept a creative technological advancement in cultivation packages offered due to technological backwardness, so the performance yield gaps cannot 
be eliminated, but their impact on declined effective and efficient resources management (Balasaheb, 2013).

Agriculture economics subject remains the most studied but unluckily least understood, this research topic Determinants of the Performance Microfinance Banks in Cane Enhancing, and its impact on Sugar Industry of Sindh limited to SCG and AE cultivators, agriculture marketers, and sugar cane industry in Sindh. Although this research conducted for Sindh province's districts like Khairpur, Nawabshah and Thatta Khairpur, Nawabshah and Thatta are largest consist of 70 percent cultivating stake of 12.5 acres to 25 acres of shareholders living in rural Sindh (Provinces of Pakistan). Land acre perquisites productive reforms being reinforced via power clots since independence but luckily not SCG and AE cultivator's performance neglected and its impact bearing the largest populace's life standard living below the poverty line. This research emphasis for land reform for irrigated and unirrigated land less than 12.5 acres and 25 acres in rural sector of Sindh. SCG and AE growers bears huge stock losses of sugar cane crops this area although demanded cash crop insurance, but unluckily neglected this research study explores State's attention. Permeability Pakistan Sugar Mills Association 2019-20 depicts in their annual accounts recorded $2 \%$ area of sugar cane plantation declined on account of water constraint for damaging sugar cane crop production. It is evident that sugar production recorded 66.33 million tons in 2019-20 as compared to 67 million tons in 2017-2018.

Regional variation of feudalism in any country makes couple of reservation, first the use of common denominator for covered range of regionally and temporally variant remain socio-economic systems could hardly be establishing fundamental rights underlying these power clots variations. Secondly, quit apart from the fact that feudalism similarly underlying these variations, was precisely defined by Harbans (1999). The significance remains dire attention from poor populace because most poor's unluckily not borrowed money scarce resources for run the family and principally for household consumption determinations. Hebrew's agriculture economics and sustainable developments emphasis in same degree foremost occupation remains almost importance of agriculture sector (Swinnen, 2010).

Agriculture economics subject remains the most studied but least understood, this research topic Determinants of the Performance Microfinance Banks in Cane Enhancing and its Impact on Sugar Industry of Sindh. This study of financing and financial issues and solution for the SCG and AE and performance of microfinance banks in enhancing the cane growing capacity and its impact on Sugar Industry of Sindh and its consumption in sugar industries. Research contains national policy choices, asking how two countries trade by the research and development strategically and contrasts can stimulate Poverty growth explained national human development in Pakistan debate about State's policy relations and any of its subsidies priorities (Tunio et. al. 2020).

Agriculture human population based in rural sector as they reliant to reigns on strategic and concentrates the research and development stimulate poverty alleviation, populace growth explained the national human population policy required in Pakistan debate about State's population policy relations and any of its subsidies priorities. Since independence agriculture remains necessary for the survival of our country that's the significance of agriculture sector was recognized but unluckily dormant in few decades and the question arises the claim of agriculture production in the country remains of a feudal in nature. In agriculture societies major relates to land remains primary productive asset. Population policies in Pakistan still require a holistic approach for human and their health act needed to legitimate towards new turn for control population in terms Welfare Economics Programme. Government should play a vital role as per population policy in Pakistan exist neglecting from so many years yet to produce its policy document (Riaz, 2016).

Objectives: Key issues needed serious attention pertains to SCG and AE cultivators are contributing in on-farm cane crop activities as well as accomplishing their domestic responsibilities without any recognition and monetary reward, the research study aims to monitor the following objectives:

- To look into the exact issues of high input of sugar cane production in Sindh.

- To investigate barrier of imbalance in income distribution.

- To investigate SCG and AE participation in the on-farm sugar cane cultivations activities.

- To find out the backwardness stands effect excel huge losses of sugar cane stocks in agriculture sector in Sindh.

\section{REVIEW OF LITERATURE}

Pakistan remains global ranked 6th in sugar cane acreage and 15th in sugar production. Sugar cane remains grown on over a million hectares and provides the raw material for fulfilling domestic needs to 
Pakistan's 84 sugar mills which contains the country's second leading agriculture industry after textiles. Agriculture cash crop leading well among the top ten sugar cane production wise nation listed globally. On another portion of portion highlighted Sindh (Province of Pakistan) cash crop sugar cane crushed stood at 15,930,655 tons Sugar made 1,719,302 tons and recovery sweetness contest at $10.79 \%$ in preceding years 2018-19 recorded by Pakistan Sugar Mills Association PSMA (2019-20), these research focus for sustainable development SCG and AE populations going forward for Sindh agriculture sector. Agriculture sector prime contributing 4.65 percent during the current year by Sugar cane, Rice, Wheat, and Cotton cash crop of the State. (Economic Survey of Pakistan, 2020-21).

Agriculture credit financing bank's should play an important role to promote the cane cultivation for improvement diverse sugar produces and its cane varieties with rational use of financing lens for SCG and AE to improve crop management with the help of best practices for growth of agriculture and development towards macroeconomics chronological performance determinations towards monitor sugar cane production in the cane crushing season, although Government should subsidize sugar varieties diversification, raw material at less than the price contents. Needs to eliminate imbalances, cane crops high weight issues, declining of sweetness sugar cane contents problems, delayed payments, false deductions, and reduce returns payment issues of SCG and AE. State's investigation required for research insight to balance lower recovery rates needed to close watch and make sure to resolve ambit of rural Sindh for cane productions (Khandker \& Samad, 2014; Chandio et al., 2021).

Economic negative growth research impact for dropping performance due to increase day to day financial problems, increase in poverty and evidence to figure out lacking its undivided attention on account of other researchers examined in their research its preoccupation in other more focus that agriculture industry needed research and development promotional support. Contextually, sugar cane industry potential dispositioned stayed dormant. Another productive step is to develop new sugar cane varieties offering diversification for better higher sugar contains impact same as particularly focus on evaluation and assessment of performance of microfinance and promotional campaign towards agriculture credit mechanism in Sindh inclusion and social farm management. This area close watch needed to monitor performance to mitigate risk of sugar cane production (Tripathi et al., 2019).

Table No. 1 List of Major Cities in Sindh (World Gazetteer 2018)

\begin{tabular}{|c|l|l|l|}
\hline Rank & City & District & Population \\
\hline 1 & Karachi & Karachi (East, West, South, Central, Malir) & $13,236,886$ \\
\hline 2 & Hyderabad & Hyderabad & $2,978,367$ \\
\hline 3 & Sukkur & Sukkur & 400,148 \\
\hline 4 & Larkana & Larkana & 322,315 \\
\hline 6 & Mirpur Khas & Mirpur Khas & 219977 \\
\hline 5 & Nawabshah & Shaheed Benazirabad & 218361 \\
\hline 7 & Jacobabad & Jacobabad & 164,248 \\
\hline 8 & Shikarpur & Shikarpur & 158,913 \\
\hline 9 & Tando Adam & Sanghar & 123,261 \\
\hline
\end{tabular}

The agriculture and industrial development required to monitor with the help of provision of all account pertains above mentioned table shown about Sugar Mills Productions, financial methodologies to be adopt by joint associations with Sub Saharan Grameen Bank Rural Agriculture Finance Institutions: sustainability and determine the sugar productions measures on the procedure profit and loss statements by sugar produces, accountability checks, pricing, as per this research effort for Agriculture Sectoral improvement, it has been concluded that all in this research paper determined the reasoning as these are proved "True" remains given below for rural Sindh.

\section{THEORETICAL FRAMEWORK}

Performance determinants pertains to analysis of directional route of cane cultivating with the help of Economic Model known as EDP model i.e., "E" used for Economics, "D" used for Development, P used for Planning combined to form an Economics of Development and Planning Model. Another researcher emphasis on Economic basic model pertains to land, labor, capital, and Entrepreneur inclusive for production to conceptualize besides produce the products and services. The basic concept 
characterizes an objective begins with $\mathrm{S}$ to Short Term pertains to $\mathrm{P}$ for Policy remains towards long Term pertains within the ambit of $\mathrm{S}$ for Strategic and $\mathrm{M}$ for Management these terms use for improvement in efficiency of the factors of production, exists in Agriculture Economic of Planning and Development (Riccardo et al., 2019).

According to the survey findings concluded studied recent research scholastically reflects for SCG and AE growers as lack of specific information needed to literate in case of farm financing towards have access to the agriculture financing from Agriculture financing for cash cane crops needed to understand facilities made available as far as security relates collaterals concerned remains same, this research approach promotional awareness for across the province of Sindh (Province of Pakistan). Further needed to resolve financial issues of SCG and AE grower's income and savings and no over dues cane crops payment in-time plans should introduce for the rural sector development for farming population of Sindh. Well-deserved promotion needed for SCG, and AE community's efforts remains our country listed the sixth in yield, the fifth leading State globally like Sugar cane remains the most important as well as primary raw material for the betterment of sugar cane production (Husan \& Shama, 2008).

Agriculture infrastructure remains initio exist fundamental development pertains to investment in training approaches preemptively, micro financial institutions should play an important role to cooperative towards making good impact in agriculture sector growth in the likely mood to continue to grow SCG and AE huge communities sector as well as monitor performance for enhancing cane capacity as well as more to develop financing credits and infrastructure development funds which remains needed to build better agriculture sector of Sindh (Province of Pakistan). Major portion pertains to research advancement towards new techniques remains progressive to aim for sugar cane cost effective measures to be taken and develop new agriculture sector with the help of microfinance growth and reduction in poverty and better economics sustainable development. State Bank of Pakistan (SBP) recorded agriculture contribution of Gross Domestic Production (GDP) declined stood at $4.1 \%$ year 2019-2020 as compared to shows 5.5\% preceding year. This research concurrence will benefit for rest of provinces of our country combine to form One Nation, towards better thematic progressive and productive for agriculture sector development through research and development teamwork and this research scholastics beneficially be applied for develops grasp of skillsets and overcome the debt and financial burden and explore the financing opportunities for the live standard improvement of Sugar Cane Grower (SCG) and Agriculture Experts (AE) agriculture sector to achieve goals of best growth and improvement towards overall economics of our country and of our Nation, as well. Another drops down portion reflects standalone picture of small and medium cane growers and demotions resulted performance declined year or year platform (SBP, 2020).

\section{MATERIAL AND METHOD}

The study was conducted in the rural areas, Sindh consist of five divisions Karachi, Hyderabad, Sukkur, Mirpur Khas and Larkana and although Sindh is divided in to 29 districts and Khairpur, Nawabshah, and Thatta very well for sugar cane production as well as highly populated, as its main reason the researcher was interested to conduct his study there. Khairpur, Nawabshah and Thatta were selected through simple random sampling technique at the first stage two groups of SCG and AE in this context 40 respondents per district were selected through cluster formed 120 sampling size. The stratified random sampling design was adopted. The research study used Stratified Random Sampling techniques; there are consists of two strata's, first stage carries out statistical surveys with a view towards making statistical inferences about the population being conducted, to understand the problems related to sugar cane crop under price, it seems imperative to determine its potential of sugar cane cost of production. At the second stage Tando Allahyar, Sanghar, Mirpur Khas and Matiari districts 32 respondents were selected through same simple random sampling techniques remains conceptualize aimed for content analysis and examined. A questionnaire with three possible responses consisting of 30 items was developed to cover four areas of critical financial issues pertaining to farming community had drawn mainly from review of the literature and in correlation with the research supervisor. A pilot study was conducted on a sample 16 item -by- item responses of the cane growers and 16 item -by-item responses of the financial institutions of the sugar industries, experts, and agriculturalists. In demographic context information and queries concerning their on-farm activities and regarding their valuation to empowerment were the critical portion of questionnaire. Like those who were to be included in the final 
sample. The draft questionnaire in respect of its meaningful wording and timing followed. SCG and AE respondents 03 possible responses recorded of 30 items was developed to cover 4 research emphasis of SCG and AE financing and financial issues unluckily unnoticed affected to SCG and AE communities which had undeveloped had drawn major focus pertains this research material and literature inferences. Chronologically, qualitative research via interviewed protocols was made the results narration statistics inferences pertains to SCG and AE group. Item by Item analysis of data. Part A SCG and AE populace. Part B interpretations has been explicated meticulously of agriculture sector economy Sindh is dependent on the quality and improvement.

Succumbing to pressure from the growers, the mills are forced to pay price for sugarcane much higher than those fixed by the government. The situation further aggravates the mills' position as they are not able to recover even the season's variable cost which affects repayment of loan installments and interest charges to the financial institutions. Data were analyzed using descriptive statistics and tendency score matching. This survey research attempts for setting up the major concept of economics development of agriculture sector of SCG and AE life standard improvement, the main instruments of resource efficacy and allocation in Sindh (Province of Pakistan). To evaluate financial problems of SCG and $\mathrm{AE}$ and its impact on sugar industries. Findings of root causes needed regularize and implement agriculture policies in Sindh. Limited options to establish sugar cane economics research work effectively and develop rural. The result shown that the small and medium sugar cane grower in average increment of grower's in concept to development agriculture of Sindh income generation. Furthermore, notwithstanding the significant losses caused by the floods, growth in the livestock sub sector was sufficient to provide much needed impetus to sectoral agrarian growth. My research dissertation pertained to financing issues of farmers and its impact on agrarian. The survey results showed that out of 250 sampled SCG and AE 184 (73.6\%) were involved cultivate sugar cane crop and the remaining 66(26.4\%) were big growers crushing other crops pertains to micro and small agricultural enterprises. Result shows that SCG and AE have significant impact on crushing cash crops making employment creation, financial inclusion, and income generation. The researcher minutely watches the benefits of micro financing and agriculture credits. (Haque, 2014).

\section{RESULTS AND DISCUSSIONS}

SCG and AE summaries the statistical inference detailed of Two Groups facing the root causes of agriculture highly populated as largest agriculture sector development finds from five regions of Sindh. Examined research it has been found that all the research explained the reasoning about the SCG, and AE groups shown given Table pertains to SCG and AE respondents were proved "True" largest population exists in agriculture rural sector in Sindh (Province of Pakistan).

Table No. 2 Land Holding

\begin{tabular}{|c|c|c|c|c|c|}
\hline \multirow[t]{2}{*}{$\begin{array}{c}\text { Sindh } \\
\text { Districts }\end{array}$} & \multicolumn{2}{|c|}{$\begin{array}{l}\text { Small Cane } \\
\text { SCG Group } 1\end{array}$} & \multicolumn{2}{|c|}{$\begin{array}{l}\text { Agriculture Experts } \\
\text { AE Group } 2 \\
12.5 \text { Acres }\end{array}$} & \multirow[t]{2}{*}{ Total } \\
\hline & $\begin{array}{l}\text { Land Holding } \\
<12.5 \text { Acres }\end{array}$ & $\begin{array}{l}\text { Land Holding } \\
>25 \text { Acres }\end{array}$ & $\begin{array}{l}\text { Land Holding } \\
<12.5 \text { Acres }\end{array}$ & $\begin{array}{l}\text { Land Holding } \\
>25 \text { Acres }\end{array}$ & \\
\hline Karachi & 60 & 20 & 2 & 17 & 99 \\
\hline Hyderabad & 50 & 10 & 2 & 9 & 71 \\
\hline Mirpur Khas & 50 & 5 & 3 & 2 & 60 \\
\hline Sukkur & 10 & 00 & 00 & 00 & 10 \\
\hline Larkana & 5 & 2 & 2 & 1 & 10 \\
\hline Total & 175 & 37 & 9 & 29 & 250 \\
\hline
\end{tabular}

Sugar cane sector commenced cane crushing seasonally operation's activities high ups climate change to measure dropping to around 55 percent, with compared to capacity at 45 percent rarely could break even, expect to grow a profitable run-in better production upcoming year (PSMA Report, 2020).

Table 3: Formulate and Implement Agriculture Policies

Narration description shown in Table 3 Reference to above table $t=1.960$ is greater than computed value $=1.33$. Hence, the null hypothesis $\mathrm{H}_{0 \mathrm{I}} \mathrm{S}$ accepted and remains concluded that Statement of SCG and $\mathrm{AE}$ have no significance difference between them administered above statement SCG and AE 
remains accepted responded for the dire need to formulate and economics farms communities needed to formulate and implement policies from the inspection of the table 1, it is clear that Sindh SCG and AE cane growers besides sugar market needed to grow in terms of free market mechanism with formulation via implementation of agriculture on the law of demand and supply basis. Further statistics shown in given Table 3 of SCG and AE Two Groups explained 'Formulate and Implement Agriculture Policies', in narration formation explained for SCG and AE presented in the following table.

\title{
Table No. 3
}

\begin{abstract}
$\mathrm{H}_{0}$ : There will be no significant difference between SCG and AE on the statement that formulate and implement policies of mixed market mechanism of agriculture economics on the basis of demand and supply.
\end{abstract}

\begin{tabular}{|l|c|c|c|c|c|}
\hline Respondents & $\mathrm{N}$ & Mean & $\mathrm{SD}$ & $\mathrm{SE} \bar{x}_{1}-\bar{x}_{2}$ & t-value \\
\hline $\mathrm{SCG}$ & 90 & $\bar{x}_{1}=146.9$ & 18.88 & \multirow{2}{*}{2.85} & 1.33 \\
\hline $\mathrm{AE}$ & 60 & $\bar{x}_{2}=150.7$ & 11.87 & \multicolumn{5}{|c|}{ tabulated $\alpha=0.05$. ' $\mathrm{t}$ ' value at $=1.960$} \\
\hline
\end{tabular}

Narration description shown in Table 4: Reference The aim of Establish sugar cane economics effectively by sustainable development techniques for Agriculture Development in Sindh (Province of Pakistan). Reference to table $t$, we find that the tabularized value of $t$ is smaller than the computed of $t=$ 3.80. Hence, the $\mathrm{H}_{0}$ is rejected, and its remains concluded that there is a significance difference about majority of SCG and AE communal thirst of advanced new techniques. remains clear that the aim of sugar cane economic effectively by develop new technique in agriculture sector. Survey methodology it's an experimental primary data research study method for task achievement for see standalone picture of SCG and AE populations facing day to day crises in their lives their reality reflects in statistical inferences analysis and examine table and interpretations have been worked for item-by-item impeccably research work concluded for Sindh (Province of Pakistan). SCG and AE detailed summary of Two Groups explained 'The aim of establish sugar cane economics effectively by develop new techniques for agriculture development for advancement shown in narration formation presented in the following table.

\section{Table No. 4}

$\mathrm{H}_{0}$ : There will be no significant difference between two groups on the statement that the aim of establish cane economics effectively by develop new techniques in Sindh (Province of Pakistan)

\begin{tabular}{|l|c|c|c|c|c|}
\hline Respondents & $\mathrm{N}$ & Mean & $\mathrm{SD}$ & $\mathrm{SE} \bar{x}_{1}-\bar{x}_{2}$ & $\mathrm{t}$-value \\
\hline SCG & 90 & $\bar{x}_{1}=153.54$ & 15.70 & \multirow{2}{*}{2.83} & 3.80 \\
\hline AE & 60 & $\bar{x}_{2}=142.78$ & 17.85 & & \\
\hline
\end{tabular}

df $=148$

tabulated $\alpha=0.05$. ' $\mathrm{t}$ ' value $=1.960$

Classification of above concurrences pertains to agriculture financing credits much reliable for agricultural sector farm communities uniform actively SCG and AE growers should avail agriculture loan scheme was presented with complete framework by State Bank of Pakistan; towards betterment inclined to make sufficient funds for bear the operating high input cost for raw material. In this context, the banks related to agriculture micro financing should show promotional perform play an important role by deliver best campaign loan for agriculture sector of Sindh with easing guarantees scheme amended from time to time remains as under agriculture financing by Bank agriculture mandatory loans and financing revolving credits etc. for SCG and AE land area planted on less than 12 acres to 25 acres' minor holdings for agriculture cane production purpose. Sugar cane economics sustainable development facing challenges agriculture sectoral investment required in a huge market of Sindh (PSMA, 2020). Microfinance agriculture financial institutions and research institutions demand to begin initializing standard system to spread knowledge of chip technology to establish push towards cashless society thus seems to root from a feasible vision of microfinance market that has bits and pieces on consumer product research findings on costing and pricing-based intervention, allocation of asset and risk credit assessments throughout evaluation via segmentation. Microfinance Institutions remains keen to enhance 
capacity of cane growing sustainable economic growth by the segmental require improve technological base momentum vis-à-vis microfinance courses need to identify therefore State should grow up on certain level prospect cost equilibrium should yield curve be maintain run major portions of operations should have to subsidized. Micro finance banks should play key role to this stage for sustainable development on segmentations remains constant need, going forward to empower the cane farm population technology environment in which the segment can grow. Essence and its origin initiative to often financial segmentations of precautionary services of financial segmentations in small, medium, low-income State's required to evaluate to serve the poor (Sainz Fernandez et al., 2018).

This research craft agriculture development interest for economics for Sugar Cane Industry and to curtail these areas demand promotions in cultivation of improved diversification in varieties with rational use of inputs and improve crop management. Pakistan Sugar Mills Association recorded during 2019 sugar cane production decreased by 0.4 to 66.880 million tons as compared to 67.174 million tons in 2018. The output may portray the pattern of cultivation i.e., 1,040 thousand hectares compared to 1,102 thousand hectares, a decline of 5.6 percent, with improved yields compared to 2018-19. Sugar Cane industry in Pakistan remains the second largest agriculture-based industry after Textiles. Pakistan remains an important cane producing country and is ranked fifth in world cane acreage and fifteenth in sugar production; its share in value added to agriculture and GDP is about 2.9 percent and in preceding year 0.6 percent, respectively (PSMA, 2020). Our Sindh largely depends on Economic agriculture development towards research and development for improvement and growth of sugar cane production portion. Pakistan provinces contributions tremendously agriculture production national income in major crops nationwide Rice production contributes of 32 percent, Sugar cane production contributes at 24 percent, Cotton production contributes at 12 percent and 21percent in Wheat Production. Our Pakistan remains top listed in fifth leading country in the world in terms of sugarcane cultivation area-wise, eleventh by sugar cane production and sixtieth in sugar cane yield (Pakistan Economic Survey, 20192020).

Sugar Cane global positioned of our country rank remains exists 6th in cane acreage and 15th in sugar production. Sugar cane remains grown on over a million hectares and provides the raw material for eighty plus sugar mills which comprises our country's second leading agro-industry after textiles. Sugar cane produces numerous valuable by-products like, fiber, fuel, chipboard manufacturing, alcohol used by pharmaceutical industry, ethanol used as a fuel, Bagasse used for paper, synthetics and organic remains a rich source of cane crop production. The Impact of Microfinance would be good on alleviation poverty and income equity distributions in Sindh. This research effort will benefit the SCG and $\mathrm{AE}$ growers cane farming community, through research and development along with building financing opportunities awareness as well as the best way in terms of Sindh, sustainable economic research and development techniques should be initiated.

\section{CONCLUSION AND RECOMMENDATION}

It is the fact of recent affairs pertains for the financial performance of the sugar cultivation on farm SCG and $\mathrm{AE}$ are so weakening day by day, its pricing per debtor is rising and productivity ratios are declined. During 2019 cane production declined by 0.4 to 66.880 million tons as compared to 67.174 million tons of preceding year 2018 and progress declined 66.300 million tons in 2020. Negative Growth of the agriculture sector plantation gaps in cane cultivation portrays the array 1,040 thousand hectares associated comparatively to 1,102 thousand hectares, a weakening of 5.6 percent, needed to close watch for the cane production for better quality yields compared to FY 2018-19 and going forward, being led through a few unmaintained sectoral issues relates high input cost operational costly and high financial burden added. The researcher penetrates in the research piece of quantification of yield gaps in different planting types of sugar cane cultivation. Government prompt action plan required for agriculture growing rapidly inclined poverty and lack of awareness issues that's led to unsustainable, illegitimate logging and its impact declining cane productions unluckily uncover insurances policy weaken implemented.

Their on-farm challenges threaten the survival of largest farm populace and damaging the vibrant agriculture services. Government should resolve financing and financial problems faced by SCG and AE largest population in Sindh pertains to challenges facing today like micro financial lens, needed to development of policy of national breeding, variance in temperature, climate change, water shortage, and changes in pattern of high input cost and increase in sugar cane produces prices. Micro financial Institutions should play a vital role towards management business strategic plan including segmentation of target market with brief description of all sugar cane produces including under development, make 
projections for current and next year, although agriculture financial institutions should practice KYC and AML procedures awareness, subsidize of essential parts for support cane productions costings side, that would help hand towards better change to ensure that SCG and AE grower's farming huge population for their future build self-efficacy to overcome financial burden and required techniques of financing stability for the agriculture sector. With strong forward and backward linkages with the secondary (industrial) and tertiary (services) sectors.

\section{REFERENCES}

Abdallah, A.-H. (2016). Agricultural credit and technical efficiency in Ghana: Is there a nexus? Agricultural Finance Review, 76(2), 309-324.

Adjognon, S. G., Liverpool-Tasie, L. S. O., \& Reardon, T. A. (2017). Agricultural input credit in subSaharan Africa: Telling myth from facts. Food Policy, 67, 93-105.

Afrin, S., Haider, M. Z., \& Islam, M. S. (2017). Impact of financial inclusion on technical efficiency of paddy farmers in Bangladesh. Agricultural Finance Review, 77(4), 484-505.

Ahmed, R., Khattak, S. W., \& Siraj, K. (2014). Impact of area under cultivation, credit disbursement and fertilizers off-take on sugarcane production: An econometric analysis. Journal of Global Innovations in Agricultural and Social Sciences, 2(4), 185-189.

Akudugu, M. A. (2011). Rural banks' financial capital and livelihoods development of women farmers in Ghana. Journal of Enterprising Communities: People and Places in the Global Economy, 5(4), 248-264.

(2012). Estimation of the determinants of credit demand by farmers and supply by rural banks in Ghana's upper East Region. Asian Journal of Agriculture and Rural Development, 2, 189-200.

(2016). Agricultural productivity, credit and farm size nexus in Africa: A case study of Ghana. Agricultural Finance Review, 76(2), 288-308.

Asadullah, M. N., \& Rahman, S. (2009). Farm productivity and efficiency in rural Bangladesh: The role of education revisited. Applied Economics, 41(1), 17-33.

Aslam, M. (2016). Agricultural productivity current scenario, constraints and future prospects in Pakistan. Sarhad Journal of Agriculture, 32(4), 289-303.

Ayaz, S., Anwar, S., Sial, M. H., \& Hussain, Z. (2011). Role of agricultural credit on production efficiency of farming sector in Pakistan: A data envelopment analysis. Pakistan Journal of Life and Social Sciences, 9(1), 38-44.

Balasaheb, D. T. (2013). Quantification of yield gaps in different planting types of sugarcane in Maharashtra. Indira Gandhi Institute of Development Research (IGIDR). Mumbai- 400065, India, pp 1-86. http://www.igidr.ac.in/pdf/publication/WP-2013-011.pdf

Bashir, M. K., Gill, Z. A., Hassan, S., Adil, S. A., \& Bakhsh, K. (2007). Impact of credit disbursed by commercial banks on the productivity of sugarcane in Faisalabad district. Pakistan Journal of Agricultural Sciences, 44(2), 361-363.

Besharat, A., \& Amirahmadi, M. (2011). The study of factors affecting productivity in the agriculture sector of Iran. African Journal of Agricultural Research, 6(18), 4340-4348.

Chandio, A. A., Jiang, Y., Joyo, M. A., \& Rehman, A. (2016). Impact of area under cultivation, water availability, credit disbursement, and fertilizer off-take on wheat production in Pakistan. Journal of Applied Environmental and Biological Sciences, 6(10), 10-18.

Chandio, A. A., Jiang, Y., Wei, F., \& Guangshun, X. (2018). Effects of agricultural credit on wheat productivity of small farms in Sindh, Pakistan: Are short-term loans better? Agricultural Finance Review, 78(5), 592-610.

Chandio, A. A., Jiang, Y., Wei, F., Rehman, A., \& Liu, D. (2017). Farmers' access to credit: Does collateral matter or cash flow matter? Evidence from Sindh, Pakistan. Cogent Economics \& Finance, 5(1), Article 1369383.

Chandio. A, Jiang Y., Rehman A., \& Akram W. (2021), Sage Open: Does Formal Credit Enhance Sugarcane Productivity? A Farm-Level Study of Sindh, Pakistan.

Denkyirah, E. K., Adu, D. T., Aziz, A. A., Denkyirah, E. K., \& Okoffo, E. D. (2016). Analysis of the factors influencing smallholder rice farmers' access to credit in the upper east region of Ghana. Asian Journal of Agricultural Extension, Economics \& Sociology, 10(4), 1-11.

Duniya, K., \& Adinah, I. (2015). Probit analysis of cotton farmers' accessibility to credit in northern Guinea Savannah of Nigeria. Asian Journal of Agricultural Extension, Economics \& Sociology, 4(4), 296-301. 
Dzadze, P., Aidoo, R., \& Nurah, G. (2012). Factors determining access to formal credit in Ghana: A case study of smallholder farmers in the Abura-Asebu Kwamankese district of central region of Ghana. Journal of Development and Agricultural Economics, 4(14), 416-423.

Emdad Haque (2017). International Journal of Climate Change Strategies and Management Multidimensional coping and adaptation strategies of small-scale fishing communities of Bangladesh to climate change induced stressors Article information available at DOI:10.1108/IJCCSM-062016-0078

Fayaz, M., Jan, D., Jan, A. U., \& Hussain, B. (2006). Effects of short term credit advanced by ZTBL for enhancement of crop productivity and income of growers. Journal of Agricultural and Biological Science, 1(4), 15-18.

Government of Pakistan. (2020). Pakistan economic survey 2019-20. https://www.finance.gov.pk/survey/chapter_20/01_Growth_and_Investment.pdf

Habib, N., Rani, S., Siddiqui, S., Zaman, S., \& Anwar, M. Z. (2014). Impact of major farm inputs on productivity of sugarcane: A case study in tehsil Kot Addu, Punjab, Pakistan. Pakistan Journal of Agricultural Research, https://www.cabi.org/gara/FullTextPDF/2015/20153118430.pdf

Husan, B., \& M. Shama (2008), Mobilizing Savings from Rural Sectors: An Initial Inquiry. Variability of financial access across rural/urban areas, provinces, Income, Household Access To Finance Is A Chronologically of its kind and is not currently available for the country. 47(1), pp.99-100

Harbans M. (2000): Social Scientist: The Feudalism Debate: https://www.jstor.org/stable/3518282 Social Scientist. Vol. 28, No. 11/12 (Nov. - Dec., 2000), pp. 70-89 (20 pages)

Hussain, A. (2013). Determinants of sugarcane productivity in Pakistan. International Journal of Environment and Rural Development, 4(2), 69-75.

Hussain, A., \& Thapa, G. B. (2012). Smallholders' access to agricultural credit in Pakistan. Food Security, 4(1), 73-85.

Iqbal, M., Ahmad, M., Abbas, K., \& Mustafa, K. (2003). The impact of institutional credit on agricultural production in Pakistan [with comments]. The Pakistan Development Review, 42(4), $469-485$.

Jan, I., \& Khan, H. (2012). Factors responsible for rural household participation in institutional credit programs in Pakistan. African Journal of Business Management, 6(3), 1186-1190.

Jan, I., Khan, S., Khan, N. P., \& Ashfaq, M. (2017). Effects of micro-credit programme of Khushali Bank limited on agricultural productivity in district Mardan, Pakistan. Sarhad Journal of Agriculture, 33(4), 501-693.

Javed, M. S., Hassan, S., Adil, S. A., Ahmad, A. S., Chattah, M. W. A., \& Nawaz, Z. (2006). Impact assessment of micro-credit programme of PRSP on crop productivity. Pakistan Journal of Agricultural Sciences, 43(3-4), 209-212.

Kassali, R., Ayanwale, A., \& Williams, S. (2009). Farm location and determinants of agricultural productivity in the Oke-Ogun area of Oyo State, Nigeria. Journal of Sustainable Development in Africa, 11(2), 1-19.

Khandker, S. R., \& Samad, H. A. (2014). Microfinance Growth and Poverty Reduction in Bangladesh: What Does the Longitudinal Data Say? The Bangladesh Development Studies, 37(1 \& 2), 127157. https://www.jstor.org/stable/26538550

Khoi, P. D., Gan, C., Nartea, G. V., \& Cohen, D. A. (2013). Formal and informal rural credit in the Mekong River Delta of Vietnam: Interaction and accessibility. Journal of Asian Economics, 26, $1-13$.

Kumar, S. M. (2013). Does access to formal agricultural credit depend on caste? World Development, 43, 315-328.

Li, X., Gan, C., \& Hu, B. (2011). Accessibility to microcredit by Chinese rural households. Journal of Asian Economics, 22(3), 235-246.

Memon, A., Khushk, A., \& Farooq, U. (2010). Adoption of sugarcane varieties in the sugarcane growing areas of Pakistan. Pakistan Journal of Agricultural Research, 23, 122-131.

Nazir, A., Jariko, G. A., \& Junejo, M. A. (2013). Factors affecting sugarcane production in Pakistan. Pakistan Journal of Commerce \& Social Sciences, 7(1), Article 50359.

Nouman, M., Siddiqi, M., Asim, S., \& Hussain, Z. (2013). Impact of socio-economic characteristics of farmers on access to agricultural credit. Sarhad Journal of Agriculture, 29(3), 469-476.

Olagunju, F., \& Adeyemo, R. (2007). Agricultural credit and production efficiency of small scale farmers in south-eastern Nigeria. Agricultural Journal, 2(3), 426-433. 
PSMA (2020). Pakistan Sugar Mills Association, Islamabad. available at www.psmacentre.com/documents/Annual Report PSMA 2020.pdf

Rehman, A., Chandio, A. A., Hussain, I., \& Jingdong, L. (2017). Is credit the devil in the agriculture? The role of credit in Pakistan's agricultural sector. The Journal of Finance and Data Science, $3(1-4), 38-44$.

Rehman, A., Chandio, A. A., Jingdong, L., \& Hussain, I. (2016). Economic perspectives of sugarcane crop in Pakistan: A time series analysis (1970-2015) (Part 4). International Journal of Advanced Biotechnology and Research, 7, 961-967.

Rehman, A., Jingdong, L., Shahzad, B., Chandio, A. A., Hussain, I., Nabi, G., \& Iqbal, M. S. (2015). Economic perspectives of major field crops of Pakistan: An empirical study. Pacific Science Review B: Humanities and Social Sciences, 1(3), 145-158.

Riaz, M., \& Muhammad, Q. (2016) Islamic Microfinance Institution: Journal of ISOSS. The Capital Structure, Growth, Performance and Value of the firm in Pakistan. Vol. 2(1), 97-101.

Riccardo et. al (2019). National Bureau of Economic Research: Business Cycle \& Currency Returns. NBER Working Paper Series Available at http://www.nber.org/papers/w26299

Sainz-F., Olmo. T. B., Gutiérrez C. L., \& Azofra S. S. (2018). Development of the Financial Sector and Growth of Microfinance Institutions: The Moderating Effect of Economic Growth. (10).3930.15-16 DOI:10.3390/su10113930

Sanusi, W., \& Adedeji, I. (2010). A probit analysis of accessibility of small scale farmers to formal source of credit in Ogbomoso zone, Oyo state, Nigeria. Agricultural Tropica et Subtropica, 43(1), 49-53.

Saqib, S. E., Ahmad, M. M., \& Panezai, S. (2016). Landholding size and farmers' access to credit and its utilisation in Pakistan. Development in Practice, 26(8), 1060-1071.

Saqib, S. E., Kuwornu, J. K., Ahmad, M. M., \& Panezai, S. (2018). Subsistence farmers' access to agricultural credit and its adequacy: Some empirical evidences from Pakistan. International Journal of Social Economics, 45(4), 644-660.

Saqib, S. E., Kuwornu, J. K., \& Panezai, S., Ali, U. (2018). Factors determining subsistence farmers' access to agricultural credit in flood-prone areas of Pakistan. Kasetsart Journal of Social Sciences, 39(2), 262-268.

Sebopetji, T., \& Belete, A. (2009). An application of probit analysis to factors affecting small-scale farmers decision to take credit: A case study of the Greater Letaba Local Municipality in South Africa. African Journal of Agricultural Research, 4(8), 718-723.

Swinnen J. (2010). Applied Economic Perspectives and Policy: The Political Economy of Agricultural and Food Policies: Recent Contributions, New Insights, and Areas for Further Research vol. 32 , issue $1,33-5$ https://econpapers.repec.org/article/oupapecpp/v_3a32_3ay_3a2010_3ai_3a1_3ap_3a3358.htm

SBP (2 020). State Bank of Pakistan, Report Agriculture Microfinance Department available at https://www.sbp.org.pk/acd/Events/targets/2020/Analysis-Oct-2020.pdf

Thirtle, C., Piesse, J., \& Gouse, M. (2005). Agricultural technology, productivity and employment: Policies for poverty reduction. Agrekon, 44(1), 37-59.

Tripathi, A. D., Mishra, R., Maurya, K. K., Singh, R. B., \& Wilson, D. W. (2019). MA: Academic Press. "Estimates for World Population and Global Food Availability for Global Health." In The Role of Functional Food Security in Gobal Health. 12(23), 9924; https://doi.org/10.3390/su12239924

Ugwumba, C., \& Omojola, J. (2013). Credit access and productivity growth among subsistence food crop farmers in Ikole Local Government Area of Ekiti State, Nigeria. Journal of Agricultural and Biological Science, 8(4), 351-356.

Yasar, A., Ali, A., Tabinda, A. B., \& Tahir, A. (2015). Waste to energy analysis of shakarganj sugar mills; biogas production from the spent wash for electricity generation. Renewable and Sustainable Energy Reviews, 43, 126-132. 